\title{
Faktor-faktor yang Mempengaruhi Pemanfaatan Jamban Keluarga di Kecamatan Jatibarang Kabupaten Brebes
}

\author{
Laeli Apriyanti"), Bagoes Widjanarko*), Budi Laksono*) \\ *) Fakultas Kesehatan Masyarakat Universitas Diponegoro Semarang \\ Korespondensi: laelifaduo@gmail.com
}

\begin{abstract}
Background: Based on Basic of Health Research in 2013, as many as 39-40 million people still defecated carelessly, including those who dumped their waste into the river. In Brebes Regency in 2017, the District Budget Fund has built 1298 latrines for poor families. But from the evaluation and preliminary studies reported that there are still many families that have not utilized the latrine to the fullest. This study aims to analyze the factors influence the utilization of family latrines in Jatibarang Subdistrict, Brebes Regency.

Method: This study is an analytic observational design using a cross sectional approach to analyze the factors influence the use of family latrines. The sample of this study was selected purposively as many as 103 heads of households involved who met the inclusion criteria, namely families who received latrine program through the district budget funds from 3 villages in Jatibarang Subdistrict.

Results: There is a significant relationship between knowledge, attitudes, defecation habits, and family support with the use of family latrines. There is no significant relationship between education level, family income, health worker support, community leaders support, availability of clean water, distance a place to defecate in addition to latrines on the use of family latrines. It is recommended that increasing knowledge and attitudes to respondents as well as supports from family were also needed in improving utilizing latrines.
\end{abstract}

Keywords: latrine utilization, enabling factors, knowledge, attitudes, family supports

\section{ABSTRAK}

Latar Belakang: Berdasarkan Riskesdas tahun 2013, sebanyak 39-40 juta orang masih buang air besar sembarangan, termasuk yang membuang kotorannya ke sungai. Di Kabupaten Brebes pada Tahun 2017 dengan Dana APBD Kabupaten telah dibangun 1298 unit jamban untuk kepala keluarga miskin. Tetapi dari hasil evaluasi dan studi pendahuluan ternyata masih banyak keluarga yang belum memanfaatkan jamban tersebut secara maksimal. Penelitian ini bertujuan untuk menganalisis faktor-faktor yang mempengaruhi pemanfaatan jamban keluarga di Kecamatan Jatibarang Kabupaten Brebes.

Metode: Penelitian ini merupakan penelitian observasional analitik dengan menggunakan pendekatan cross sectional untuk menganalisis faktor-faktor yang berpengaruh terhadap pemanfaatan jamban keluarga. Sampel penelitian ini dipilih secara purposive sebanyak 103 kepala keluarga yang memenuhi kriteria inklusi yakni keluarga yang mendapat bantuan jamban melalui dana APBD Kabupaten yang berasal dari 3 desa di Kecamatan Jatibarang.

Hasil: Terdapat hubungan yang signifikan antara pengetahuan, sikap, kebiasaan buang air besar, dan dukungan keluarga dengan pemanfaatan jamban keluarga.Tidak ada hubungan yang signifikan antara tingkat pendidikan, pendapatan keluarga, dukungan tenaga kesehatan, dukungan tokoh masyarakat, ketersediaan air bersih, jarak tempat buang air besar selain jamban terhadap pemanfaatan jamban keluarga. Disarankan selain peningkatan pengetahuan dan sikap kepada responden, diperlukan juga contoh dan dukungan dari tokoh masyarakat dalam pemanfaatan jamban.

Kata Kunci: pemanfaatan jamban, faktor pemungkin, pengetahuan, sikap, dukungan keluarga 


\section{PENDAHULUAN}

Permasalahan kesehatan di Indonesia masih ditandai dengan tingginya angka kesakitan dan kematian penyakit yang berbasis lingkungan. Kondisi tersebut banyak dijumpai di daerah pedesaan. Penyakit yang penularannya berkaitan dengan air dan lingkungan terutama penyakit diare masih endemis dan merupakan masalah kesehatan yang belum selesai. ${ }^{(1)}$ Berdasarkan data WHO bahwa kematian yang disebabkan karena waterborne disease mencapai 3.400 .000 jiwa per tahun, dan penyakit diare merupakan penyebab kematian terbesar yaitu 1.400 .000 jiwa per tahun. Dari semua kematian tersebut penyebabnya berakar pada sanitasi dan kualitas air yang buruk. ${ }^{(2)}$

Perilaku buang air besar sembarangan (BABS) masih banyak terjadi di Indonesia. Di sejumlah daerah, masyarakat masih membuang air besar sembarangan di kali atau sungai. Data Joint Monitoring Program WHO/ UNICEF 2014, sebanyak 55 juta penduduk di Indonesia masih berperilaku buang air besar sembarangan. Berdasarkan data Riset Kesehatan Dasar (Riskesdas) tahun 2013, sebanyak 39-40 juta orang yang BAB sembarangan, termasuk orang yang mempunyai jamban. Riset yang dilakukan UNICEF dan WHO, juga menyatakan lebih dari 370 balita di Indonesia meninggal akibat perilaku buruk dari perilaku BAB sembarangan. Selain penyakit, perilaku BAB sembarangan juga memperbesar risiko yang menghambat pertumbuhan fisik anak-anak. ${ }^{(3)}$

Hasil Riskesdas 2013 tentang proporsi rumah tangga berdasarkan penggunaan fasilitas buang air besar, menunjukkan bahwa perilaku buang air besar di jamban adalah $82,6 \%$. Sementara Provinsi Jawa tengah menduduki urutan ke-15 dengan penduduk berperilaku baik buang air besar di jamban yakni sebesar 62,7\%. Data BPS Pusat tahun 2014 menunjukkan bahwa persentase kepemilikan jamban keluarga di Jawa Tengah sebesar $72,49 \%$. $^{(4)}$

Di Provinsi Jawa Tengah masih ditemukan penduduk yang buang air besar di area terbuka yaitu sebanyak 2.025.723 jiwa. ${ }^{(5)}$ Data penduduk yang memanfaatkan jamban mengalami peningkatan dari tahun 2011-2013. Pada tahun 2011 sebesar 68\%, $2012(70,46 \%)$ dan 2013 (76,11\%), sedangkan tahun 2014 menurun menjadi $76 \%$. $^{(6)}$ Namun, penduduk dengan akses jamban di tahun 2015 meningkat kembali menjadi $78,82 \%$. Sementara di Kabupaten Brebes, masih terdapat penduduk yang buang air besar sembarangan yaitu sebanyak 140.129 jiwa $(26,09 \%) .{ }^{(5)}$ Berdasarkan STBM online Kementerian Kesehatan RI pada tahun 2018 bahwa masih ada penduduk Kabupaten Brebes yang BAB Sembarangan yaitu sebanyak 
140.129 KK (26,09\%) sedangkan penduduk yang sudah akses sanitasi jamban sehat sebesar 396.970 KK (73,91\%). Kabupaten Brebes terdiri dari 17 Kecamatan dan 297 Desa/ Kelurahan, hanya 24 desa dari 297 desa/Kelurahan yang sudah ODF (Open Defecation Free), sedangkan sisanya 273 desa masih terjadi OD(Open Defecation ). ${ }^{(5)}$

Berdasarkan data Profil Dinas Kesehatan Kabupaten Brebes pada Tahun 2015 angka kejadian diare masih cukup tinggi mencapai 13.230 jiwa, sedangkan pada Tahun 2016 diketahui ada peningkatan kasus angka kejadian diare mencapai $29.430 \quad$ Jiwa. ${ }^{(6,7)}$ Sedangkan berdasarkan data profil Dinas Kesehatan Kabupaten Brebes pada Tahun 2017, ada kasus kematian balita akibat diare sebanyak 2 orang balita. ${ }^{(8)}$ Data tersebut membuktikan bahwa masih banyak masyarakat yang tidak memanfaatkan jamban.

Dalam rangka mempercepat pencapaian Kabupaten ODF (Open Defecation Free), Pemerintah Kabupaten Brebes telah mengalokasikan dana APBD Tahun Anggaran 2017 untuk pembangunan jamban sebanyak 1298 unit yang diberikan kepada Kepala Keluarga miskin yang belum mempunyai jamban. Jamban yang telah dibangun dengan Dana APBD tersebut sebanyak 1298 unit. Pembangunan jamban tersebut tersebar di
87 Desa, yang termasuk wilayah kerja di 23 Puskesmas di 10 Kecamatan. Berdasarkan hasil monitoring dan evaluasi pasca pembangunan jamban yang dilakukan oleh Tim Dinas Kesehatan Kabupaten Brebes, dari 300 KK yang disurvei, masih ditemukan $10 \mathrm{KK}$ belum memanfaatkan jamban yang telah dibangun.

Berdasarkan penjelasan dan uraian tersebut, peneliti tertarik untuk meneliti lebih lanjut mengenai faktor - faktor yang berhubungan dengan pemanfataan jamban keluarga di Kecamatan Jatibarang. Faktor yang diteliti yaitu faktor predisposing yang meliputi: tingkat pendidikan, tingkat pengetahuan tentang jamban keluarga, sikap tentang jamban keluarga dan kebiasaan atau tradisi buang air besar. Faktor penguat (reinforcing factor) yaitu dukungan keluarga, petugas kesehatan dan dukungan tokoh masyarakat. Sementara faktor pemungkin (enabling factor) meliputi: tingkat pendapatan keluarga, ketersediaan air, jarak rumah ke tempat BAB selain jamban.

\section{METODE}

Jenis penelitian ini adalah survei analitik dengan menggunakan pendekatan Cross-sectional. Sampel dalam penelitian ini terdiri dari Kepala keluarga yang mendapat bantuan jamban dana APBD kabupaten di wilayah Kecamatan 
Jatibarang yang memenuhi kriteria inklusi yaitu sebanyak $103 \quad$ kepala keluarga.Teknik. Pengumpulan data menggunakan teknik wawancara dengan instrumen berupa kuesioner yang telah diuji validitas dan reliabilitas, sedangkan lembar observasi digunakan untuk mengecek penggunaan jamban oleh keluarga yang kemudian hasil pengolahan dan analisis data tersebut dilakukan dengan uji Chi-Square dan logistic regression. Data disajikan dalam bentuk tabel dan narasi. Penelitian ini telah mendapatkan persyaratan etik dari Komite Etik Penelitian Kesehatan Fakultas Kesehatan Masyarakat Universitas Diponegoro Semarang dengan No. 070/EC/FKM/2018.

\section{HASIL DAN PEMBAHASAN}

\section{Karakteristik Responden}

Karakteristik responden yang diteliti meliputi umur, pendidikan, pekerjaan, jumlah anggota keluarga,dan pendapatan keluarga seperti pada tabel 1 , menunjukkan bahwa umur responden ratarata berumur 48 tahun dengan umur minimum 27 tahun dan maksimum 55 tahun. Responden yang berumur kurang dari 48 tahun lebih sedikit $(47,6 \%)$ proporsinya dibandingkan dengan yang sama dan lebih dari 48 tahun $(52,4 \%)$. Kebanyakan berjenis kelamin perempuan, dengan tingkat pendidikan rendah (SD dan SMP) sebanyak 92,2\%. Pekerjaan terbanyak adalah wiraswasta diikuti buruh dan ibu rumah tangga sebanyak masing2 $(20,4 \%)$. Lebih dari separuh $(58,3 \%)$ responden mempunyai anggota keluarga lebih dari 4 orang dan kebanyakan responden berpendapatan rendah $(76,5 \%)$. Untuk lebih jelasnya dapat dilihat pada tabel 1.

\section{Pemanfaatan Jamban Keluarga}

Hasil penelitian menunjukkan bahwa sebagian besar responden memanfaatkan jamban sebesar 79,61\% dan sisanya $20,39 \%$ tidak memanfaatkan jamban yang sudah diberikan. Dari yang sudah memanfaatkan jamban hampir seluruh anggota keluarga termasuk anakanak dan orang tua telah menggunakan jamban $(79,61 \%)$, sedangkan responden yang termasuk kurang memanfaatkan jamban karena masih ada beberapa anggota keluarganya yang masih sering buang air besar di sungai. 
Tabel 1. Karakteristik responden

\begin{tabular}{llcc}
\hline No & Karakteristik Responden & Frekuensi & Persentase \\
\hline 1 & Umur & & \\
& $<48$ Th & 49 & 47,6 \\
& $\geq 48$ Th & 54 & 52,4 \\
\hline 2 & Jenis Kelamin & & \\
& Laki-laki & 45 & 43,7 \\
& Perempuan & 58 & 56,3 \\
\hline 3 & Pendidikan & & \\
& Rendah & 95 & 92,2 \\
& Tinggi & 8 & 7,8 \\
\hline 4 & Pekerjaan & & \\
& Wiraswasta & 43 & 41,7 \\
& Buruh & 21 & 20,4 \\
& Petani & 18 & 17,5 \\
& Tidak bekerja/IRT & 21 & 20,4 \\
\hline 5 & Jumlah anggota keluarga & & \\
& <4 Orang & 43 & 41,7 \\
& 24 Orang & 60 & 58,3 \\
\hline 6 & Pendapatan keluarga & & \\
& Rendah & 79 & 76,7 \\
& Tinggi & 24 & 23,3 \\
\hline
\end{tabular}

Tabel 2. Distribusi frekuensi pemanfaatan jamban keluarga

\begin{tabular}{lcc}
\hline \multicolumn{1}{c}{ Pemanfaatan jamban } & $\mathrm{n}$ & $\%$ \\
\hline Kurang & 21 & 20,39 \\
Baik & 82 & 79,61 \\
\hline Jumlah & 103 & 100 \\
\hline
\end{tabular}

Untuk tercapainya keberhasilan program, selain disediakan jamban oleh pemerintah, masyarakat diminta untuk berpartisipasi melengkapi jamban dengan membuat dinding pembatas dari bahan plastik, kayu, bambu, ataupun material lainnya sesuai dengan kemampuan mereka sehingga jamban tersebut dapat langsung digunakan. Kegiatan monitoring pasca pembangunan jamban dilakukan oleh kader dan tokoh masyarakat agar masyarakat dapat merubah perilakunya dan tidak lagi BAB di sungai atau dikebun. 
Tabel 3. Hubungan antara tingkat pengetahuan dengan pemanfaatan jamban

\begin{tabular}{lllrrrrr}
\hline & & \multicolumn{3}{c}{ Pemanfaatan jamban } & \multicolumn{2}{c}{ Total } \\
\cline { 3 - 6 } No & \multirow{2}{*}{ Pengetahuan } & \multicolumn{2}{c}{ Kurang } & \multicolumn{2}{c}{ Baik } & \multicolumn{2}{c}{$(\mathrm{n}=103)$} \\
\cline { 3 - 7 } & & $\mathrm{f}$ & $\%$ & $\mathrm{f}$ & $\%$ & $\mathrm{f}$ & $\%$ \\
\hline 1 & Kurang & 14 & 33,3 & 28 & 66,1 & 42 & 100 \\
2 & Baik & 7 & 11,5 & 54 & 88,5 & 61 & 100 \\
\hline
\end{tabular}

\section{Hubungan Tingkat Pengetahuan dengan Pemanfaatan Jamban}

Berdasarkan hasil penelitian menunjukkan bahwa sebagian besar responden yang kurang memanfaatkan jamban lebih banyak $(33,3 \%)$ terdapat pada yang berpengetahuan kurang tentang dampak BAB sembarangan seperti penyakit diare, dan penyakit akibat sanitasi yang buruk lainnya, dibandingkan dengan yang berpengetahuan baik (11,5\%), demikian juga sebaliknya. Hasil uji statistik Chi-Square di peroleh nilai $p$ value $0,014(\rho<0,05)$, yang berarti ada hubungan yang signifikan antara tingkat pengetahuan responden dengan pemanfaatan jamban keluarga.

Pengetahuan merupakan hasil tahu dari suatu objek. Pengetahuan terjadi setelah melakukan pengamatan atau penginderaan terhadap suatu objek. Penginderaan terhadap suatu objek terjadi melalui panca indra manusia yaitu penglihatan, pendengaran, penciuman, rasa, dan raba. Sebagian besar pengetahuan diperoleh melalui mata dan telinga. ${ }^{(9)}$
Menurut Budioro yang menyatakan bahwa dengan adanya rangsangan dari luar seperti informasi/penyuluhan tentang sanitasi dan kesehatan lingkungan serta dampaknya terhadap kejadian penyakit akibat sanitasi yang buruk akan membentuk pengetahuan seseorang yang akhirnya dapat segera berubah ke pengetahuan yang lebih baik, dan menuju perubahan perilaku. ${ }^{(10)}$ Hasil penelitian itu sejalan dengan penelitian yang pernah dilakukan bahwa ada hubungan yang signifikan antara pengetahuan seseorang dengan pemanfaatan jamban keluarga. ${ }^{(11)}$ Hasil penelitian sebelumnya juga menjelaskan bahwa pengetahuan mempengaruhi tingkat pemanfaatan jamban dengan baik. ${ }^{(12)}$ Hasil penelitian lainnya mengemukakan bahwa pengetahuan merupakan salah satu pendorong untuk seseorang merubah perilaku. Dengan demikian maka dapat dikatakan bahwa pengetahuan seseorang tentang jamban akan menentukan perilakunya dalam hal buang air besar. ${ }^{(13)}$ Penyuluhan yang sering dilakukan oleh puskesmas tentang dampak dari sanitasi 
yang buruk dan lingkungan yang kurang baik, membuat masyarakat lebih sadar akan pentingnya kebersihan diri dan lingkungan termasuk pemanfaatan jamban untuk buang air besar.

\section{Hubungan Sikap terhadap Jamban} dengan Pemanfaatan Jamban

Berdasarkan hasil penelitian menunjukkan bahwa responden yang tidak memanfaatkan jamban keluarga lebih banyak pada reponden yang bersikap kurang terhadap pemanfaatan jamban(31,0\%) dibandingkan dengan yang bersikap baik $(13,1 \%)$. Hasil uji statistik Chi-Square di peroleh nilai $\rho$ value $=0,005$ $(\rho<0,05)$, yang berarti terdapat hubungan antara sikap responden dengan pemanfaatan jamban keluarga.

Sikap merupakan reaksi atau respon seseorang yang masih tertutup terhadap suatu stimulus atau objek tertentu, yang sudah melibatkan faktor pendapat dan emosi yang bersangkutan. Sikap juga merupakan suatu sindrom atau kumpulan gejala dalam merespon stimulus atau objek. Sehingga sikap itu melibatkan pikiran, perasaan, perhatian dan gejala kejiwaaan yang lain. Setelah seseorang mendapatkan stimulus atau objek berupa penyuluhan, ajakan dari petugas kesehatan dan lingkungan sosialnya, proses selanjutnya ia akan menilai atau bersikap terhadap stimulus atau objek tersebut. ${ }^{(9)}$ Hal ini sejalan dengan penelitian terdahulu bahwa terdapat hubungan yang signifikan antara sikap dengan pemanfaatan jamban. ${ }^{(11)}$ Hasil penelitian yang lain juga menjelaskan bahwa sikap seseorang mempengaruhi tingkat pemanfaatan jamban dengan baik. ${ }^{(3)(7)}$

Tabel 4. Hubungan antara sikap terhadap jamban dengan pemanfaatan jamban

\begin{tabular}{|c|c|c|c|c|c|c|c|}
\hline \multirow{3}{*}{ No } & \multirow{3}{*}{ Sikap } & \multicolumn{4}{|c|}{ Pemanfaatan jamban } & \multirow{2}{*}{\multicolumn{2}{|c|}{$\begin{array}{c}\text { Total } \\
(\mathrm{n}=103)\end{array}$}} \\
\hline & & \multicolumn{2}{|c|}{$\begin{array}{c}\text { Tidak } \\
\text { memanfaatkan }\end{array}$} & \multicolumn{2}{|c|}{ Memanfaatkan } & & \\
\hline & & $\mathrm{f}$ & $\%$ & $\mathrm{f}$ & $\%$ & $\mathrm{f}$ & $\%$ \\
\hline 1 & Kurang & 13 & 31,0 & 29 & 69,0 & 42 & 100 \\
\hline 2 & Baik & 8 & 13,1 & 53 & 86,9 & 61 & 100 \\
\hline
\end{tabular}


Tingkat pengetahuan responden terhadap pemanfaatan jamban mayoritas sudah cukup baik sehingga mempengaruhi sikap responden dalam memanfaatkan jamban. Hal tersebut juga ditunjang dengan teori yang menjelaskan bahwa sikap merupakan dasar untuk membuat berperilaku dalam cara yang tertentu yang dipilihnya. ${ }^{(14)}$ Sikap merupakan kesiapan untuk bereaksi terhadap suatu objek dengan cara-cara tertentu. Kesiapan yang dimaksud adalah kecenderungan potensial untuk bereaksi dengan cara tertentu jika individu dihadapkan pada stimulus yang menghendaki adanya respons. ${ }^{(15)}$

Rusli Ibrahim mengatakan bahwa sikap merupakan kesiapan mental untuk berbuat, dan karena itu, dapat dipergunakan untuk meramal perilakunya. Sikap dapat berkembang melalui pengalaman langsung dan komunikasi antara perseorangan. Melalui proses demikian, keyakinan berkembang atau berubah, dan disimpan dalam memori ingatan. ${ }^{(14)}$ Sikap seseorang dapat berubah dengan diperolehnya tambahan informasi tentang obyek tersebut, melalui persuasi serta tekanan dari kelompok sosialnya. ${ }^{(16)}$

$$
\text { Buang air besar sembarangan }
$$
merupakan salah satu dari berbagai masalah kesehatan yang perlu mendapatkan prioritas. Penyediaan sarana pembuangan tinja masyarakat terutama dalam pelaksanaannya tidaklah mudah,

karena menyangkut peran serta masyarakat yang biasanya sangat erat kaitannya dengan sikap dan perilaku. Bila dikaitkan dengan penggunaan jamban keluarga, sikap masyarakat sangat tergantung dari pendapat terhadap kebiasaan yang selama ini telah dijalankan. Faktor psikologis seperti rasa nyaman, rasa kebersamaan saat melakukan BABS, faktor ketersediaan air dan rasa lainnya dapat menjadi penghambat untuk berperilaku $\mathrm{BAB}$ dijamban. Bila dikaitkan dengan teori Green dan Marshall, kebiasaan buang air besar selain didukung dengan tersedianya sarana, faktor kemampuan diri untuk BAB dijamban, yang mendukung seseorang untuk merubah perilakunya juga menentukan seseorang dalam bertindak. responden yang telah terbiasa buang air besar di jamban akan mendukung untuk buang air besar dijamban, untuk itu di tahap awal seseorang harus bersikap positif, dan merasa mampu, dan dilatih terus menerus sehingga membentuk rasa nyaman bila BAB dijamban. ${ }^{(16)}$

\section{Hubungan Tingkat Penghasilan}

\section{Keluarga dengan Pemanfaatan Jamban}

\section{Keluarga}

Responden yang $r$ tidak
memanfaatkan jamban keluarga lebih
banyak pada responden yang
berpenghasilan rendah dibandingkan
dengan yang berpenghasilan tinggi. Hasil


uji statistik Chi-Square di peroleh nilai $\rho$ value $1,000(\rho>0,05)$, yang berarti tidak ada hubungan antara penghasilan keluarga terhadap pemanfaatan jamban keluarga. Status ekonomi seseorang menentukan tersedianya suatu fasilitas yang diperlukan untuk kegiatan tertentu, sehingga status sosial ekonomi ini mempengaruhi perubahan perilaku pada diri seseorang. Tingkat pendapatan berkaitan dengan status ekonomi keluarga yang akan berpengaruh pada status kesehatan masyarakat.

Penelitian yang menyatakan bahwa tidak adanya perbedaan risiko antara responden yang berpenghasilan rendah dengan yang berpenghasilan tinggi karena responden dengan penghasilan yang tinggi juga memiliki kecenderungan yang sama yaitu tidak memiliki sarana pembuangan tinja yang layak, karena responden yang bersangkutan dapat memanfaatkan lingkungan pinggir kali untuk $\mathrm{BAB}$ sehingga tidak mengalokasikan dana untuk pembangunan sarana jamban di rumah. Selain itu walaupun keluarga ini masuk dalam kategori penghasilan tinggi, pemberian jamban gratis bagi keluarga ini menandakan mereka sebetulnya termasuk berpenghasilan rendah dibandingkan masyarakat umum lainnya.
Hubungan Dukungan Tenaga Kesehatan dengan Pemanfaatan Jamban Keluarga

Berdasarkan hasil penelitian menunjukkan bahwa sebagian besar responden yang mendapat dukungan tenaga kesehatan, memanfaatkan jamban dalam kategori baik $(86,1 \%)$.

Hasil uji statistik Chi-Square di peroleh nilai $\rho$ value $=0,07 \quad(\rho>0,05)$, yang berarti tidak ada hubungan antara dukungan tenaga kesehatan terhadap pemanfaatan jamban keluarga.

Fungsi atau peran petugas kesehatan adalah membina peran serta masyarakat dalam rangka meningkatkan kemampuan untuk hidup sehat. Dalam hal penggunaan jamban, kegiatan yang dilakukan oleh petugas kesehatan antara lain adalah memberikan penyuluhan secara berkala tentang manfaat dan syarat-syarat jamban sehat, juga melakukan pembinaan kepada masyarakat untuk meningkatkan kesadaran dan kemauan masyarakat memiliki dan menggunakan jamban keluarga. Tenaga kesehatan walaupun sebagai orang yang dipercaya oleh masyarakat, tetapi biasanya mereka adalah bukan bagian dari masyarakat di daerah tersebut. 
Pemanfaatan jamban tidak terwujud bila masyarakat belum terbentuk keyakinan akan manfaat dari perilaku tersebut. Bila intensitas penyuluhan tidak kontinyu atau tidak cukup membentuk keyakinan, maka peran petugas belum dapat membentuk keyakinan masyarakat dalam merubah perilaku pemanfaatan jamban. $^{(16)}$

\section{Hubungan Dukungan Keluarga dengan Pemanfaatan Jamban Keluarga}

Berdasarkan hasil penelitian menunjukkan bahwa sebagian besar responden yang mendapat dukungan keluarga, memanfaatkan jamban dalam kategori baik $(90,9 \%)$.

Hasil uji statistik chi-square di peroleh nilai $\rho$ value $=0,000(\rho<0,05)$, hal ini berarti ada hubungan yang signifikan antara dukungan keluarga dengan pemanfaatan jamban.

Dukungan keluarga adalah pernyataan responden tentang dukungan yang diberikan oleh angggota keluarga. Kategori variabel ini digolongkan menjadi 2 yakni dukungan keluarga baik dan kurang. Responden yang mendapat dukungan keluarga baik, lebih banyak yakni $66(70 \%)$ orang daripada responden yang kurang dukungan keluarga yakni sebanyak 37 orang (28\%).

Hasil analisis bivariat bahwa responden yang memanfaatkan jamban, lebih banyak yang mendapat dukungan keluarga yakni 60 Orang $(90,9 \%)$ dibandingkan dengan yang tidak mendapatkan dukungan keluarga (70\%). Dukungan keluarga menjadi penting untuk membentuk perilaku dalam satu keluarga. Bila perilaku pemanfaatan jamban didukung oleh seluruh keluarga, maka dengan mudah seluruh keluarga untuk berperilaku pemanfaatan jamban. Keluarga dengan pendidikan relatif baik dan berpenghasilan baik akan lebih mudah menerima informasi yang disampaikan oleh petugas kesehatan dalam penggunaan jamban. ${ }^{(12)}$

\section{Hubungan Dukungan Tokoh} Masyarakat dengan Pemanfaatan Jamban Keluarga

Berdasarkan hasil penelitian menunjukkan bahwa sebagian besar responden yang mendapat dukungan tokoh masyarakat dalam memanfaatkan jamban dengan kategori baik sebanyak (80,2\%). Hal ini menunjukkan bahwa tokoh masyarakat telah memberikan sikap yang positif dan mendukung penggunaan jamban keluarga.

Hasil uji statistik Chi-square di peroleh nilai $\rho$ value $=0,770(\rho>0,05)$, hal ini berarti tidak ada hubungan yang signifikan antara dukungan tokoh masyarakat terhadap pemanfaatan jamban keluarga. Hal ini menunjukkan karena 
dukungan yang diberikan positif cukup banyak persentasenya tetapi penggunaan jamban masih belum sebanyak yang menyatakan dukungan oleh tokoh masyarakat. Dukungan tokoh masyarakat saja belum dapat merubah perilaku masyarakat dalam pemgggunaan jamban, sehingga dibutuhkan variabel lain dalam membentuk perilaku. ${ }^{(16)}$

Dukungan tokoh masyarakat adalah dukungan yang diperoleh dari hubungan interpersonal yang mengacu pada kesenangan,ketenangan, bantuan manfaat, yang berupa informasi verbal yang diterima seseorang atau masyarakat dari tokoh masyarakat yang dapat membawa efek perilaku seseorang. Tokoh masyarakat adalah role model bagi masyarakat sehingga selain anjuran, tokoh masyarakat juga harus memberikan contoh perilaku yang dapat diikuti oleh masyarakat. ${ }^{(16)}$

\section{Hubungan Ketersediaan Air Bersih dengan Pemanfaatan Jamban Keluarga}

Sebagian besar responden yang mempunyai ketersediaan air bersih memanfaatkan jamban dalam kategori baik $(79,4 \%)$ dibandingkan yang tidak mempunyai ketersediaan air bersih. Hasil uji statistik Chi-square di peroleh nilai $\rho$ value $1,000(\rho>0,05)$, hal ini berarti tidak ada hubungan antara ketersediaan air bersih terhadap pemanfaatan jamban keluarga.
Menurut Permenkes RI Nomor 416/Menkes/Per/IX/1990, pasal 1 (c) menyatakan bahwa air bersih adalah air yang digunakan untuk keperluan seharihari yang kualitasnya memenuhi syarat kesehatan dan dapat diminum apabila dimasak. Kebutuhan air bersih sehari-hari untuk keperluan jamban keluarga sebanyak 45 liter perorang perhari. Jamban yang diberikan pemerintah memerlukan air untuk membersihkannya. Bila masyarakat ketersediaan airnya kurang maka pemanfaatan jamban juga menjadi kurang. Dalam hal ini responden penelitian memerlukan peningkatan ketersediaan air, karena hanya $80 \%$ responden mudah dalam memenuhi ketersediaan air.

\section{Hubungan Akses ke Tempat BAB Selain} Jamban dengan Pemanfaatan Jamban

\section{Keluarga}

Berdasarkan hasil penelitian menunjukkan bahwa sebagian besar responden mempunyai akses mudah ke tempat BAB selain jamban sebanyak $(83,6 \%)$. Hal ini menunjukkan bahwa tempat tinggal responden kebanyakan dekat dengan sungai, parit atau kebun atau persawahan yang sering dijadikan tempat BABS.

Hasil uji statistik Chi-square di peroleh nilai $\rho$ value $=0,335(\rho>0,05)$, hal ini berarti tidak ada hubungan antara kemudahan akses ke tempat BAB selain 
jamban terhadap pemanfaatan jamban keluarga. Pemanfaatan jamban terjadi bukan hanya karena dekat dan jauhnya tempat tinggal responden dengan sungai, parit, kebun atau persawahan tempatnya BABS masyarakat, tetapi juga kemungkinan faktor lain seperti pengetahuan, sikap, kenyamanan, dukungan keluarga, dan lainnya.

\section{Analisis Multivariat}

Analisis ini bertujuan untuk mengetahui pengaruh variabel-variabel bebas secara bersama-sama terhadap variabel terikat. Dari table 6 diketahui bahwa pengetahuan memiliki Odd Ratio = 3,077 (95\%CI (1,273-7,295). Hal ini berarti bahwa pengetahuan yang baik tentang sanitasi dan manfaat jamban keluarga, memungkinkan responden untuk memanfaatkan jamban keluarga sebesar 3,077 kali dibandingkan dengan yang memiliki pengetahuan yang kurang.

Sedangkan dukungan
memiliki Odd Ratio $=4,553(95 \% \mathrm{CI}$

Tabel 6. Hasil Analisis Regresi Logistik pada pemanfaatan jamban keluarga di Kecamatan Jatibarang Kabupaten Brebes

\begin{tabular}{|c|c|c|c|c|c|c|}
\hline \multirow[t]{2}{*}{ No } & \multirow[t]{2}{*}{ Variabel } & \multirow[t]{2}{*}{ B } & \multirow{2}{*}{$\begin{array}{c}p- \\
\text { value }\end{array}$} & \multirow{2}{*}{$\begin{array}{l}\text { Exp } \\
\text { (B) }\end{array}$} & \multicolumn{2}{|c|}{$\begin{array}{l}95,0 \% \text { CI Exp } \\
(\beta)\end{array}$} \\
\hline & & & & & Lower & Upper \\
\hline 1 & Pengetahuan & 1,124 & 0,013 & 3,077 & 1,273 & 7,295 \\
\hline 2 & Dukungan keluarga & 1,516 & 0,001 & 4,553 & 1,818 & 10,818 \\
\hline & Konstant & $-1,550$ & 0,001 & 0,212 & & \\
\hline
\end{tabular}


Sedangkan variabel yang berpengaruh terhadap pemanfaatan jamban keluarga adalah pengetahuan responden dan dukungan keluarga. Pengetahuan baik responden memungkinkannya untuk memanfaatkan jamban sebesar 3 kali dibandingkan dengan pengetahuan kurang. selanjutnya dukungan keluarga yang baik juga memungkinkan pemanfaatan jamban 4 kali lebih besar dibandingkan dengan dukungan keluarga kurang. Disarankan bahwa, peningkatan pengetahuan dan sikap melalui pemberian informasi yang intensif dan mempengaruhi kognitif masyarakat dibutuhkan agar peningkatan penggunaan jamban keluarga menjadi meningkat.

\section{KEPUSTAKAAN}

1. Kementerian Kesehatan RI. Modul Pelatihan Stop Buang Air Besar Sembarangan. Jakarta: Ditjen pengendalian penyakit dan penyehatan lingkungan; 2011.

2. Kementerian Kesehatan RI. Road Map Percepatan Program STBM 2013-2015. Jakarta: Direktorat PP dan PL Kementerian Kesehatan RI; 2013. 1-4 p.

3. Kementerian Kesehatan Republik Indonesia. BAB Sembarangan [Internet]. 2015. Available from: http://mediakom.sehatnegeriku.com/ bab-sembarangan/

4. Kementerian Kesehatan Republik
Indonesia. Profil Kesehatan Indonesia Tahun 2013. Jakarta: Kementerian Kesehatan Republik Indonesia; 2014. 178-181 p.

5. Kementerian Kesehatan Republik Indonesia. Sanitasi Total Berbasis Masyarakat [Internet]. Jakarta: Direktorat P2PL Kemenkes RI; 2016. Available from: http://www.stbm-indonesia.org/

6. Dinas Kesehatan Provinsi Jawa Tengah. Buku Saku Kesehatan Provinsi Jawa Tengah Tahun 2014. Semarang: Dinas Kesehatan Provinsi Jawa Tengah; 2015. 98 p.

7. Dinas Kesehatan Kabupaten Brebes. Profil Kesehatan Kabupaten Brebes Tahun 2015. Brebes: Dinas Kesehatan Kabupaten Brebes; 2015.

8. Dinas Kesehatan Kabupaten Brebes. Profil Kesehatan Kabupaten Brebes Tahun 2016. Brebes: Dinas Kesehatan Kabupaten Brebes; 2016.

9. Notoatmodjo S. Ilmu Perilaku. Jakarta: Rineka Cipta; 2010.

10. Notoatmodjo S. Promosi Kesehatan dan Perilaku Kesehatan. In Edition. Jakarta: Rineka Cipta; 2012.

11. Anggoro FF, Khoiron, Ningrum PT. Analisis faktor yang berhubungan dengan pemanfaatan jamban di Kawasan Perkebunan Kopi. e-Jurnal Pustaka Kesehat. 2014;3:171-8.

12. Dunggio D. Faktor - faktor yang 
Faktor-faktor yang Mempengaruhi Pemanfaatan... (Laeli A., Bagoes W., Budi L.)

mempengaruhi perilaku masyarakat tentang penggunaan jamban di Desa Modelomo Kecamatan Tilong Kabupaten Bone Bolango Tahun 2012. Universitas Negeri Gorontalo; 2012.

13. Antuli N. Faktor Determinan yang mempengaruhi perilaku buang air besar di Desa Sogu Kecamatan Monano. Universitas Negeri
Gorontalo; 2012.

14. Sarlito. Pengantar Umum Psikologi. Jakarta: Bulan Bintang; 2002.

15. Azwar S. Sikap manusia teori dan pengukurannya. Yogyakarta: Pustaka Pelajar; 2009.

16. Ogden J. Health Psychology A Text Book. Buhkingham, Phidelphia: Open University Pess; 1996. 20-23 p. 